\title{
Analysing the Moderating Effects of Generational Cohorts on Brand Loyalty in the Malaysian Footwear Industry
}

\author{
(Menganalisis Kesan Generasi sebagai Moderator terhadap Kesetiaan Jenama bagi
} Industri Kasut di Malaysia)

\author{
Lai Ruixia \\ Teo Siew Chein \\ (Faculty of Business, Multimedia University)
}

\begin{abstract}
This study aims to determine if the factors affecting brand loyalty in the footwear industry are moderated by generational cohorts (Baby Boomers, Generation X, and Millennials). It also examines if product quality, product style, produce price, brand image, service quality, and store environment are antecedents to brand loyalty in the Malaysian footwear industry. Insights into brand loyalty in Malaysia's footwear industry would help domestic brands gain customer loyalty and allow penetration into the global footwear market. Web-based, selfadministrated survey questionnaires were distributed to 200 respondents. Several statistical analyses were performed using SPSS 22 software. The results indicate that four of the predetermined antecedents, product quality, product style, brand image, and store environment significantly influence brand loyalty in the Malaysian footwear industry. Malaysian footwear consumers from different age groups (generational cohorts) also revealed different purchasing patterns and buying behaviour.
\end{abstract}

Keywords: Brand loyalty; footwear industry; generational cohort; Malaysia

\section{ABSTRAK}

Kajian ini meneliti sekiranya faktor yang mempengaruhi kesetiaan jenama dalam industri kasut boleh dipengaruhi oleh kohort generasi (Baby Boomers, Generasi X dan Milenium) sebagai moderator. Projek ini juga mengkaji jika kualiti produk, gaya produk, harga produk, imej jenama, kualiti perkhidmatan dan persekitaran kedai merupakan faktor yang mempengaruhi kesetiaan jenama dalam industri kasut Malaysia. Pemahaman tentang kesetiaan jenama dalam industri kasut Malaysia dapat membantu jenama domestik memperolehkan kesetiaan pelanggan dan membolehkan penembusan ke dalam pasaran kasut global. Borang soal selidik web yang diurus secara kendiri telah diedarkan kepada 200 orang responden. Analisis statistik telah dilakukan menggunakan perisian SPSS 22. Keputusan menunjukkan bahawa empat faktor, iaitu, kualiti produk, gaya produk, imej jenama dan persekitaran kedai ketara mempengaruhi kesetiaan jenama dalam industri kasut Malaysia. Kohort generasi juga bertindak sebagai moderator dengan mempengerauhi corak pembelian dan tabiat membeli pengguna kasut Malaysia.

Kata kunci: Kesetiaan terhadap jenama; industri kasut; kohort generasi; Malaysia 


\section{INTRODUCTION}

Malaysia is a key player in Asia's footwear industry as Asia's 13th largest footwear producer and exporter. The industry is one of the country's oldest manufacturing activities, yielding an annual capacity of approximately 70 million pairs (Italian Trade Agency 2012; MATRADE 2015). It consists of roughly 1,000 footwear manufacturers, with a workforce of approximately 30,000 (Malaysia Insights 2014; Italian Trade Agency 2012). In recent years, Malaysia's footwear industry and its exports have made a major leap in value, with RM 493 million in 2014 (MATRADE 2015), RM 584.7 million in 2015, and RM 715.5 million in 2016 (MATRADE 2017).

Currently, however, Malaysia's footwear industry is in a precarious situation. Malaysia's footwear exports fell 12\% for the first eight months of 2017, with the exception of sportswear, which continues to increase in demand. Exports fell 13.8\% year-on-year in 2017 to RM 652.7 million (MATRADE 2017; Aznam Shah 2018). Although Malaysia's footwear industry has successfully established its own brands, including Dr Cardin, Crocodile, Larrie, Jimmy Chia, Terry Wilson, MISANO, and UNIFIT (Italian Trade Agency 2012; MATRADE 2015), Malaysia is still widely recognised for its original equipment manufacturing (OEM), producing such global brands as Puma, Nike, and Adidas. The local footwear industry has been urged by MATRADE (Aznam Shah 2018) to innovate and produce locally made premium brands to stay relevant. Thus, Malaysia's footwear manufacturers are eager to find ways to increase their market share. This can be achieved only by establishing brand loyalty among consumers. Hence, identifying the key factors that influence brand loyalty among Malaysians is key to gaining market share and, consequently, to achieving a sustainable advantage over competitors. To the best of the author's knowledge, the last and only study on brand loyalty that focused on Malaysia footwear industry was conducated by Wong and Sidek (2008) a decade ago. This study could serve to enrich the available literature in terms of the factors affecting brand loyalty on footwear industry in Malaysia

Statistics on brand loyalty by Fundera (2017) reveal that $43 \%$ of customers spend more on their loyal brands; $65 \%$ of company business comes from existing customers, and $20 \%$ of existing customers will be responsible for $80 \%$ of future profits. As such, recent marketing efforts have shifted from acquiring new customers to retaining old customers to counter the effects of increased market ambiguity and reduced product differentiation (Kinuthia et al. 2012). Nevertheless, brand loyalty is a tricky business, because the act of repurchasing alone is not sufficient evidence of brand loyalty, because the practice of purchasing must be intentional (Che Wel, Shah Alam \& Mohd Nor 2011).

In an effort to achieve brand loyalty, marketing experts have studied how to achieve multigenerational marketing. According to Williams and Page (2014), multi-generational marketing is the practice of fulfilling the desires of individuals in various generational cohorts. Generational cohorts are groups of similar age who have experienced similar life events because they lived during a specific period (Pentecost \& Andrews 2010). A marginally larger share of Millennials (84\%) claimed to be brand loyal to certain brands of products than Gen X $(83 \%)$ and Baby Boomers (81\%)(Industry Insights 2017).

There are limited literatures on brand loyalty towards footwear industry, and majority of the relevant studies were conducted outside of Malaysia (Anitha 2014; Dai \& Chen 2017; Khoei 2014; Kinuthia et al. 2012; Krishnakumar \& Kavitha 2014; Li 2013; Lim \& Aprianingsih 2015; Singh 2016). These studies suggest that product quality, brand image, price, product quality, product style, service quality and store environment are important factors influencing brand loyalty in footwear products. Lim and Aprianingsih (2015) posit that product syle has significant influence on brand loyalty although similar studies by others have indicated otherwise (Wong \& Sidek 2008; Dai \& Chen 2017). Wong and Sidek (2008) 
claimed that service quality and store environment have significant contribution to brand loyalty, however, Dai and Chen (2017) have obtained diverse conclusions. Since mixed findings were reported on their influence on brand loyalty in footwear industry, therefore it is necessary to examine these factors particularly in the context of Malaysia as cultural, geographical, and socio-economic differences between countries may have an effect on brand loyalty. In addition, none of these previous studies examine the effect of multigenerational marketing. Therefore, the primary objective of this research is to determine if the factors affecting brand loyalty in the footwear industry are moderated by generational cohorts (Baby Boomers, Generation X, and Millennial). It also attempts to examine if the predetermined factors (product quality, product style, product price, brand image, service quality, and store environment) are antecedents to brand loyalty in the Malaysian footwear industry.

\section{LITERATURE REVIEW}

\section{BRAND LOYALTY}

In the simplest terms, brand loyalty is a consumer's high relative purchasing attitude towards one brand by practising recurring purchases because the brand offers the right product features, image, and quality at the most suitable price (Wong \& Sidek 2008). There are, however, many definitions of brand loyalty. For instance, whereas Muhammad, Seyyed Mohammad, and Nima (2013) define brand loyalty as a behavioural response of customers that leads them to purchase a specific brand, Che Wel et al. (2011) see brand loyalty as a combination of behavioural responses and psychological processes that influence both the behaviours and attitudes of consumers to practise the recurring purchase of a particular brand. Further, Wong and Sidek (2008) and Kinuthia et al. (2012) define brand loyalty as the extent to which a consumer prefers one brand over all other available brands, because that one brand has fulfilled all or most of the consumer's requirements.

Although the definitions and constructs of brand loyalty have evolved tremendously over the years, it is important to note that the theories and understanding of brand loyalty existed only at a behavioural level through Copeland's academic studies in 1923 (Maheshwari, Lodorfos \& Jacobsen 2014). From its behavioural constructs, brand loyalty was further developed into the theory that repeated purchase happens only if price, functionality, and quality of a product or service meet the customer's expectations. This concept then led to the recognition of the attitudinal aspect as an important factor of brand loyalty. Following that, marketing efforts also began to focus on building relationships and creating value for customers, once researches learned that brand loyalty also has emotional components. This meant that, in addition to repurchase intentions, customers must also have a connection or commitment towards a brand on an emotional level. Hence, overall positive feelings and past experience are both important drivers of brand loyalty.

Several other theories on brand loyalty have been put forward. Wong and Sidek (2008) posit the two aspects of brand loyalty: the behavioural and the attitudinal. The behavioural perspective indicates that the action of repurchasing from a brand is sufficient evidence of brand loyalty. Meanwhile, the attitudinal trait regards only the practice of recurring purchase as the basis of brand loyalty, which requires supporting a positive predisposition towards the brand to ensure that the repurchasing behaviour will be continuous. Attitudinal loyalty is based on consumers' views, and it describes consumers' biases, promises, or buying purposes towards a specific brand (Dai \& Chen 2017). This study adopts the attitudinal loyalty approach and regards brand loyalty as the willingness of respondents to recommend a footwear brand. 
Various empirical studies have investigated brand loyalty in the footwear industry. A study by Li (2013) demonstrates that the factors influencing brand loyalty to footwear in China included perceived value (image and price) and perceived quality (reliability, tangibles, empathy, responsiveness, assurance), whereas Dai and Chen (2017) found that product quality and brand name significantly affect brand loyalty towards sportswear among Hong Kong university students. On the other hand, Singh (2016) states that good functional quality, various sizes and colours, price-increase effect, interior environment, trained sales personnel, prompt service, brand image, informative advertising, reliability, and customer experience were factors important for brand loyalty in India. Nevertheless, it is crucial to acknowledge that factors that influence brand loyalty vary demographically and geographically. Therefore, this research aims to study the brand loyalty of the Malaysian footwear industry specifically.

\section{PRODUCT QUALITY}

According to Stevenson and Chuong (2014), quality is regarded as the ability of a product or service to consistently meet or exceed consumers' requirements and expectations. Quality is also a customer-dependent aspect that changes with various customers' personal requirements. Meanwhile, other significant definitions of product quality include the result of a product's performance that is free from any form of defect (Hayan \& Samaan 2015) and a consumer's assessment of a product's overall excellence or superiority that includes intrinsic and extrinsic factors (Thompson, Newman \& Liu n.d.)

According to Ferencic and Wolfling (2013), the characteristics that must be considered when determining product quality are a product's capability to (1) fulfil its primary purpose, (2) last long and be maintenance-easy, (3) be used safely, (4) be well designed, (5) have a good brand image and reputation, and (6) lead to total consumer satisfaction from continual use. If a product is able to achieve a satisfactory level in all of these aspects, its product quality is high.

Product quality plays a crucial role in brand loyalty by influencing consumer purchasing behaviour, as it gives consumers a relatively good reason to buy from a specific brand (Abdullah 2015). Similar to the aspects of brand loyalty, product quality allows a brand to be differentiated from its competitors and empowers a brand to charge a higher price for its product quality thanks to its high performance and durability (Muhammad et al. 2013). According to Krishnakumar and Kavitha (2014), this practice is particularly true for perfectionists, who are consumers that would go to great lengths to identify and distinguish the quality level of various brands before making a purchase. Consequently, once consumers have found and experienced a brand that provides a product whose quality meets or exceeds their expectations, they become loyal to that particular brand (Che Wel et al. 2011). This leads to the first hypothesis.

$\mathrm{H}_{1}$ Product quality has a significant positive relationship with brand loyalty in the footwear industry among Malaysians

\section{PRODUCT STYLE}

A product's style plays an important role in building brand personalities and creating characteristics of a product's image (Horvath 2001). At the same time, it can become a brand's competitive advantage by becoming the basis for product differentiation (Creusen \& Schoormans 2005). Wong and Sidek (2008) and Khoei (2014) define product style as the details, line, and silhouette that make up a product's visual appearance. As an aspect of product style, Creusen and Schoormans (2005) state that product appearance plays six important roles for consumers: (1) communication of aesthetic, (2) symbolic, (3) functionality impression, (4) ergonomic information, (5) attention drawing, and (6) categorisation. 
Style is also an attribute of the present whose characteristics do not change, but can evolve into an entirely new style (North, De Vos \& Kotze 2003). Eventually, if it prevails among consumers, a style becomes a fashion. Consumers are becoming more aware of fashion trends and demanding more stylish products (Krishnakumar \& Kavitha 2014). Now, consumers tend to match their attire to various occasions, thus signalling the footwear industry to improve their product styles. A product style that appeals greatly to a consumer will create a relational affiliation between the consumer and the brand, because a product style reflects the brand's personality. As such, stylish brands would inevitably entice fashion conscious consumers to be loyal (Wong \& Sidek 2008). This leads to the development of this research's second hypothesis.

$\mathrm{H}_{2}$ Product style has a significant positive relationship with brand loyalty in the footwear industry among Malaysians

\section{PRODUCT PRICE}

In simple terms, product price is the specific monetary value that a customer assigns to a good or service (Dhurup, Mafini \& Dumasi 2014). According to Li (2013), it can also be defined as the cost incurred by a consumer when making a purchase. Product price is the most important consideration for the average consumer in purchasing decision and action (Wong \& Sidek 2008; Kinuthia et al. 2012; Krishnakumar \& Kavitha 2014). Lim and Aprianingsih (2015) state that brand loyalists are less sensitive to price changes because of the perceived high risks associated with switching products or brands. Hence, consumers are more comfortable sticking with their preferred brand despite a price hike.

When it comes to purchasing decisions and actions, consumers are always equipped with a predetermined range of acceptable product prices. Therefore, if a product is priced much lower or higher than the consumer's suitable price, the consumer may not proceed with the purchasing action (Indrayani, Siringoringo \& Saptariani 2008). Product price, which influences brand loyalty, communicates the perceived quality or the brand's intended positioning value of a product (Kinuthia et al. 2012). A consumer gains satisfaction and will proceed with a purchasing decision when a product's perceived value is greater than its perceived cost $(\mathrm{Li}$ 2013). Hence, with its ability to retain existing customers or attract potential customers, product price symbolises a unique opportunity to establish long-term relationships or brand loyalty by communicating a product's perceived value or quality (Dhurup et al. 2014). Singh (2016) found that a satisfactory pricing strategy and customer satisfaction are the two most important factors affecting brand loyalty in the footwear industry in Ludhiana, India. Fundera (2017) reported that price and value were ranked as the top reasons to remain brand loyal by $92 \%$ of loyal customers. This leads to the third hypothesis.

$\mathrm{H}_{3}$ Product price has a significant positive relationship with brand loyalty in the footwear industry among Malaysians

\section{BRAND IMAGE}

Rubini (2010) describes brand image as the mental picture or existing idea about a brand in the consumers' minds. Muhammad et al. (2013) define brand image as what consumers understand about a brand. A brand's image can be seen as a body of attitude that is based one group's attitude. According to Kinuthia et al. (2012), consumers often use their possessions to portray their ideal self; therefore, consumers prefer brands with personality traits that match their desired character. Similar to Rubini's (2010) definition, Lin and Chang (2013) see brand image as the combination of concepts, emotions, and attitudes that arise when a consumer thinks of a 
brand. Li (2013) adds that a company's operation, which includes its perceived value, service quality, and customer satisfaction, also influences a brand's image. Therefore, the process of developing a successful brand image is costly and time-consuming (Wong \& Sidek 2008).

A theory developed by Lin and Chang (2013) divide brand image into three distinct categories: functional image, symbolic image, and experiential image. The first category, functional image, addresses the feelings consumers have about a product's design, practicality, and reputation. The symbolic image of a brand reflects the brand's social status, personal style, and interpersonal relationship with its consumers. Finally, experiential image portrays a brand's interest, warmth, joyfulness, and self-expression. Therefore, the fourth hypothesis of this research aims to study this relationship in the context of the Malaysian footwear market.

$\mathrm{H}_{4}$ Brand image has a significant positive relationship with brand loyalty in the footwear industry among Malaysians

\section{SERVICE QUALITY}

Service quality is the standard of service that meets and satisfies the needs and requirements of consumers (Lim \& Aprianingsih 2015). Zehir et al. (2011) define service quality as the disparity between a consumer's expectations of service and the perceptions of service actually received. Service quality consists of two dimensions, namely functional and technical (Chumpitaz \& Swaen 2003; Wong \& Sidek 2008). The technical dimensions of service quality are the practices, systems, and groundwork that deliver a service. Functional service quality considers the way service is provided, including employees' courtesy, attitude, professionalism, and promptness. SERVQUAL is another important model of service quality; it consists of five aspects: (1) reliability, (2) empathy, (3) tangibles, (4) responsiveness, and (5) assurance (Li 2013; Poku, Zakari \& Soali 2013).

In a marketing context, service quality is an economic activity that aims to create value for customers (Poku et al. 2013). It is believed that consumers often prefer to shop at particular stores because they are assured of certain service privileges, and they appreciate the value of the services provided. Some of the important elements of service quality to consumers are interaction quality, physical environment quality, and outcome quality (Zehir et al. 2011). This leads to the development of the fifth hypothesis.

$\mathrm{H}_{5}$ Service quality has a significant positive relationship with brand loyalty in the footwear industry among Malaysians

\section{STORE ENVIRONMENT}

Many studies regard store environment as the most crucial factor, determining the success of retail marketing through store longevity (Wong \& Sidek 2008; Hamza Salim 2011; Lim \& Aprianingsih 2015). A store's positive qualities, which include its location, layout, and stimuli, would affect a customer's brand loyalty, because the customer's perceived satisfaction would propel him or her to revisit the store in future (Choi, Heo \& Kim 2012). Choi et al. (2012) name the surrounding elements of a store, such as functionality, aesthetics, and convenience, as the qualities important to promoting brand loyalty through brand satisfaction. Hamza Salim (2011) adds that a store's other environmental aspects, such as the salespeople's characteristics, interior colours, smell, signs, and temperature, are also crucial to a customer's purchasing behaviour and action.

A store's environment also provides a significant opportunity to create and strengthen a brand's rational and emotional relationship with its customers (Kumar \& Kim 2014). A rational relationship is achieved when a consumer's purchasing process is made more convenient and 
easier, creating a positive purchasing experience value. At least $82 \%$ of US adults revealed that their loyalty to a product brand will increase if they have a chance to touch and try on the products (Industry Insights 2017).

A theory by Assuncao et al. (2013) explains that store environment is important in two aspects: ambient smell and layout. According to them, ambient smell is the human sense that has the most effect on emotional reactions. The second factor, layout, can be divided further into five categories: (1) store exterior, (2) store interior, (3) layout design, (4) decoration, and (5) human variables. Although store environment is the common factor of brand loyalty least studied and tested, results from empirical studies have demonstrated the significant impact that the store environment has on brand loyalty (Choi et al. 2012; Hamza Salim 2011; Assuncao et al. 2013). For the purpose of this research, the store environment theory by Assuncao et al. (2013) is used as it consists of more comprehensive and holistic factors. Hence, the following hypothesis is proposed.

$\mathrm{H}_{6}$ Store environment has a significant positive relationship with brand loyalty in the footwear industry among Malaysians

\section{GENERATIONAL COHORTS}

According to Lissitsa and Kol (2016), the generational cohort theory is a structure that determines a way to segment a population into different categories. A generational cohort can be defined as the years of birth (20-25 years) or the duration taken for a group of births to be born, age and, consequently, have their own children. Researchers and academics have agreed that, because these cohorts were born during the same periods, they would have experienced common life experiences and, thus, would have similar values, preferences, and behaviours (Parment 2013; Lissitsa \& Kol 2016; McCrindle 2011; Gilboa \& Vilnai-Yavetz 2010). More importantly, these shared values, thoughts, and attitude would endure and persist throughout the entire generations' life times and, unavoidably, become an identity of the particular generation (Lissitsa \& Kol 2016); each generational cohort would have a significantly unique purchasing pattern and shopping behaviour (Gilboa \& Vilnai-Yavetz 2010).

The three generations studied in this research are the Baby Boomers, the Generation $\mathrm{X}$, and the Millennials. Although there are many age ranges with slight discrepancies in years for each generation, for this research Parment's (2013) generational age ranges are used because the ranges of age are more consistently apart. The Baby Boomers were born in the period 19461964 and are 52-70 years old as of 2016 (McCrindle 2011; Jackson, Stoel \& Brantley 2011). According to Gilboa and Vilnai-Yavetz (2010), the Baby Boomers are workaholics who emphasise work and personal sacrifice as the road to success. Canning (2017) claimed that Baby Boomers are not easy to win over, but once loyalty is won, they will remain loyal forever.

The cohort born in the period 1965-1985 is known as Generation X (Parment 2013). Therefore, as of 2016, they were 31-51 years old. The Millennials are known as a generation that is able to adapt easily to change and thus, are acknowledged as independent, entrepreneurial, and savvy (Gilboa \& Vilnai-Yavetz 2010). As consumers, Generation X-ers appreciate high quality products and excellent customer service at an affordable price (Wagner 2018). In all, $86 \%$ of Generation X-ers would switch brands if they experienced poor service (Glover 2018).

Finally, the Millennials (Generation Y) were born in the period 1986-2002 and were 1430 years old as of 2016 (Parment 2013). According to Gilboa and Vilnai-Yavetz (2010), the Millennials are optimistic, self-confident, self-esteemed, impatient, and achievement-oriented. As consumers, the Millennials are generally big spenders who are highly selfish, spontaneous, and very brand conscious. Brandmovers (2018) revealed that $80 \%$ of Millennials would change 
their brand loyalty if this can save money. The last hypotheses of this research will evaluate if there are significant moderating effects of generational cohort on the six predetermined factors that might affect brand loyalty in the Malaysian footwear industry.

$\mathrm{H}_{7 \mathrm{a}}$ Generational cohort significantly moderates the relationship between product quality and brand loyalty in the footwear industry among Malaysians.

$\mathrm{H}_{7 \mathrm{~b}}$ Generational cohort significantly moderates the relationship between product style and brand loyalty in the footwear industry among Malaysians.

$\mathrm{H}_{7 \mathrm{c}}$ Generational cohort significantly moderates the relationship between product price and brand loyalty in the footwear industry among Malaysians.

$\mathrm{H}_{7 d}$ Generational cohort significantly moderates the relationship between brand image and brand loyalty in the footwear industry among Malaysians.

$\mathrm{H}_{7 \mathrm{e}}$ Generational cohort significantly moderates the relationship between service quality and brand loyalty in the footwear industry among Malaysians.

$\mathrm{H}_{7 \mathrm{f}}$ Generational cohort significantly moderates the relationship between store environment and brand loyalty in the footwear industry among Malaysians.

\section{RESEARCH METHODOLOGY}

Figure 1 presents the proposed conceptual framework for this research

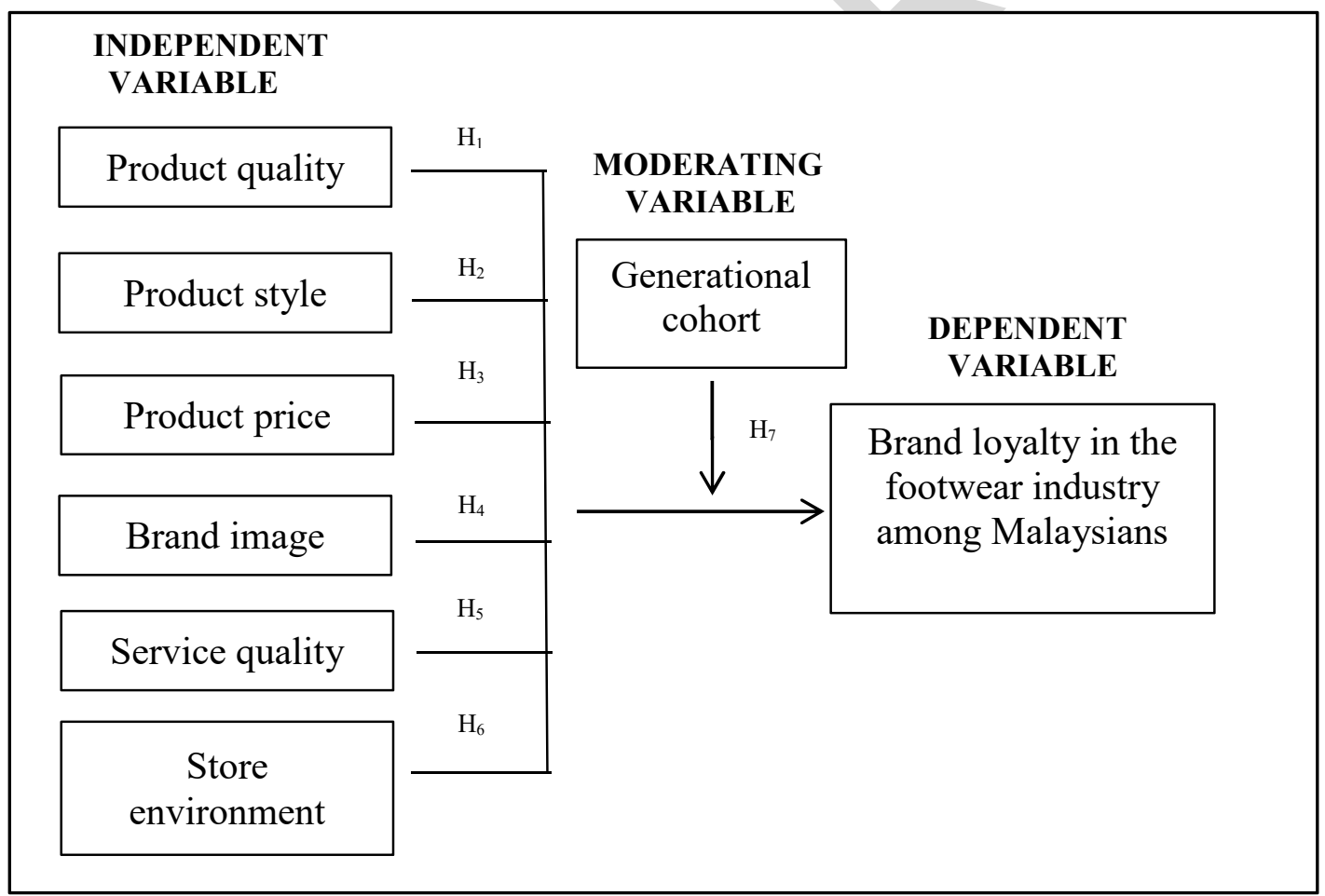

Source: Adapted from Wong and Sidek (2008) and Krishnakumar and Kavitha (2014).

FIGURE 1. Theoretical framework

\section{SAMPLING DESIGN}

For the purpose of this research, primary data were collected via self-administered, web-based survey questionnaires. The target population for this research study was Malaysians between the ages of 14 and 70 that have owned or purchased any form of footwear. According to 
Sekaran and Bougie (2010) and Hill (1998), the guiding principle behind choosing the appropriate sample size for a research study is between 30 and 500 sample units, as it would achieve an acceptable degree of sampling error. Therefore, for the purpose of this research, a total sample size of 200 respondents was chosen. To accurately depict the diversity of the Malaysian population's generational cohort, a quota sampling technique was deemed appropriate, as stated by Neuman (2012). Table 1 shows the predetermined number of respondents for each generational cohort based on quota sampling techniques. After that, a snowball sampling technique was applied, which involved getting responses from initial respondents. This sampling method was chosen as it saved time, because the initial respondents would readily know several acquaintances or family members that would fit the predetermined generational categories of samples.

TABLE 1. The sampling size breakdown of the quota sampling technique

\begin{tabular}{ccccc}
\hline $\begin{array}{c}\text { Generational } \\
\text { cohort }\end{array}$ & Age range & $\begin{array}{c}\text { Malaysia's } \\
\text { population }\end{array}$ & $\begin{array}{c}\text { Percentage of } \\
\text { population }\end{array}$ & $\begin{array}{c}\text { Sample } \\
\text { quotas }\end{array}$ \\
\hline Baby Boomers & $52-70$ years old & 4563956 & 22.3400 & 45 \\
Generation X & 31-51 years old & 8362869 & 40.9353 & 82 \\
The Millennial & 14-30 years old & 7502675 & 36.7247 & 73 \\
\hline & Total & $\mathbf{2 0 4 2 9 5 0 0}$ & $\begin{array}{c}\text { Total } \\
\text { respondents }\end{array}$ & $\mathbf{2 0 0}$ \\
\hline
\end{tabular}

Source: Adapted from Live Population (2010)

\section{QUESTIONNAIRE DESIGN}

The questionnaire consists of three main sections. Part $A$ poses demographic questions. Part $B$ consists of general questions regarding the respondents' preferred brand of footwear and brand loyalty practices. Finally, Part $C$ contains questions concerning the construct measurements of this study's six independent variables and dependent variable. Table 2 summarises the samples' profile

TABLE 2. Respondents' demographic profile

\begin{tabular}{|c|c|c|c|}
\hline Demographic & & Frequency & Percent \\
\hline Gender & $\begin{array}{l}\text { Male } \\
\text { Female }\end{array}$ & $\begin{array}{r}79 \\
121\end{array}$ & $\begin{array}{l}39.5 \\
60.5\end{array}$ \\
\hline Age Group & $\begin{array}{l}1430 \text { years old } \\
3151 \text { years old } \\
5270 \text { years old }\end{array}$ & $\begin{array}{l}73 \\
82 \\
45\end{array}$ & $\begin{array}{l}36.5 \\
41.0 \\
22.5\end{array}$ \\
\hline Ethnic Group & $\begin{array}{l}\text { Malay } \\
\text { Chinese } \\
\text { Indian } \\
\text { Others }\end{array}$ & $\begin{array}{r}16 \\
147 \\
36 \\
1\end{array}$ & $\begin{array}{r}8.0 \\
73.5 \\
18.0 \\
.5\end{array}$ \\
\hline Marital status & $\begin{array}{l}\text { Single } \\
\text { Married } \\
\text { Others }\end{array}$ & $\begin{array}{r}130 \\
69 \\
1\end{array}$ & $\begin{array}{r}65.0 \\
34.5 \\
.5\end{array}$ \\
\hline $\begin{array}{l}\text { Monthly gross } \\
\text { income or } \\
\text { allowance }\end{array}$ & $\begin{array}{l}\text { Below RM2000 } \\
\text { RM2000 RM3000 } \\
\text { RM3000 RM4000 } \\
\text { RM4000 and above }\end{array}$ & $\begin{array}{l}80 \\
48 \\
41 \\
31\end{array}$ & $\begin{array}{l}40.0 \\
24.0 \\
20.5 \\
15.5\end{array}$ \\
\hline $\begin{array}{l}\text { Highest education } \\
\text { level }\end{array}$ & $\begin{array}{l}\text { PMR/SPM/OLevel } \\
\text { STPM/Foundation/ }\end{array}$ & $\begin{array}{r}6 \\
32\end{array}$ & $\begin{array}{r}3.0 \\
16.0\end{array}$ \\
\hline
\end{tabular}




\begin{tabular}{llrr} 
& Diploma/ALevel & & \\
& Bachelor's Degree & 137 & 68.5 \\
Masters & 17 & 8.5 \\
& PhD Doctorate & 6 & 3.0 \\
& Others & 2 & 1.0 \\
Occupation's status & Not in the labour force & 60 & 30.0 \\
& Employed & 107 & 53.5 \\
& Unemployed & 11 & 5.5 \\
& Retired & 15 & 7.5 \\
Others & 7 & 3.5 \\
\hline
\end{tabular}

\section{RESEARCH INSTRUMENT}

There are 35 statements as a measurement construct to the six variables, namely product quality, product style, product price, brand image, service quality, and store environment, as well as the dependent variable (brand loyalty), shown in Table 3. All statements in this section were evaluated using a 7-point Likert level of agreement scale: $1=$ strongly disagree, $2=$ disagree, $3=$ somewhat disagree, $4=$ neutral, $5=$ somewhat agree, $6=$ agree, and $7=$ strongly disagree. The 7-point Likert scale was chosen as studies have exhibited increased scale sensitivity or number of scale options, with a midpoint respond choice drawing more accurate and desirable responses (Tsang 2012).

TABLE 3. Construct measurements questions

\begin{tabular}{ll}
\hline Variables & Construct Measurements Questions \\
\hline Product Quality & The brand uses materials that are comfortable \\
& The brand's footwear size fits me very well \\
The brand has sufficient colours options & The brand has good functional quality \\
& *The brand produces footwear that meet my basic requirements \\
Product Style & The brand provides a wide variety of styles \\
& The brand provides styles that are trendy and fashionable \\
& The brand provides styles that are suitable for me \\
& The brand providse styles that have unique features \\
& *The brand provides styles that attract me easily \\
The brand provides good value for money & \\
The brand's prices do not affect my purchase decisions & *The brand 's footwear are reasonably priced \\
*Even if the prices of the brand's product were to increases, I would still \\
continue purchasing from the same brand \\
* If alternative brands are on discount, I would still purchase from my \\
preferred brand \\
The brand image is reputable \\
The brand image reflects my own personality \\
The brand image attracts me to make a purchase \\
The brand is selected regardless of price \\
*The brand has given me pleasurable brand experiences before \\
Brand Image \\
The employees at the brand's stores have neat and clean appearances \\
The employees at the brand's stores are friendly and courteous \\
The employees at the brand's stores are very well trained \\
The employees at the brand's stores are always ready to help me \\
The employees at the brand's stores are efficient when dealing with \\
customer complaints
\end{tabular}

Source
Wong \& Sidek
$(2008)$

Wong \& Sidek (2008)

Wong \& Sidek (2008)

Wong \& Sidek (2008)

Wong \& Sidek (2008), Zehir et al. (2011) 
Store

Environment

The brand's stores have good locations and are easy to access

The brand 's stores interior displays are attractive

The brand's stores colour schemes are pleasing

The brand's stores lightings are pleasing to me

The brand's stores environment makes it pleasurable to shop in

Brand Loyalty I intend to continue purchasing from this brand for the next few years

I have no intention to replace my choice of brand

I would recommend this brand to my family and friends

I say positive things about this brand to other people

I consider myself to be very loyal to this brand
Wong \& Sidek (2008), Kumar $\& \operatorname{Kim}(2014)$

Chong et al. (2015)

\section{RESULTS ANALYSIS \\ RELIABILITY ANALYSIS}

Table 4 presents Cronbach's alpha reliability and descriptive analysis performed for this study. All relevant variables resulted in an alpha coefficient greater than 0.7 and thus, all variables were accepted for further analytical tests. All of the mean scores are greater than 4, which indicates that respondents agreed with most of the statements; product quality has the highest mean score of 5.8000, whereas product price has the lowest mean score of 4.8890 .

TABLE 4. Reliability analysis, mean, and standard deviation scores

\begin{tabular}{lcccc}
\hline \multicolumn{1}{c}{ Variable } & N of items & Cronbach's alpha & Mean & SD \\
\hline Product quality & 5 & 0.78 & 5.8000 & 0.65617 \\
Product style & 5 & 0.81 & 5.5800 & 0.79698 \\
Product price & 5 & 0.75 & 4.8890 & 0.82589 \\
Brand image & 5 & 0.75 & 5.1020 & 0.71481 \\
Service quality & 5 & 0.79 & 5.2980 & 0.62349 \\
Store environment & 5 & 0.76 & 5.1720 & 0.67580 \\
Brand loyalty & 5 & 0.86 & 5.4220 & 0.81759 \\
\hline
\end{tabular}

\section{MULTIPLE LINEAR REGRESSION ANALYSIS}

A multiple regression was calculated to predict brand loyalty based on product quality, product style, product price, brand image, service quality, and store environment, as shown in Table 5. The coefficient of determination value is 0.473 . This indicates that approximately $47.30 \%$ of the dependent variable (brand loyalty) can be explained by the variances in the model.

TABLE 5. Model summary and analysis of variance

\begin{tabular}{llll}
\hline Models & Sum of squares & d.f. & Mean square \\
\hline Regression & 62.948 & 6 & 10.491 \\
Residual & 70.075 & 193 & .363 \\
Total & 133.023 & 199 & \\
\hline
\end{tabular}

$\mathrm{R}=0.688, \mathrm{R}^{2}=0.473$, Adjusted $\mathrm{R}^{2}=0.457, \mathrm{SE}$ of the Estimate $=0.60256 . \mathrm{F}$-value $=28.895, \mathrm{Sig}=0.0009$

TABLE 6. Summary of regression coefficient

\begin{tabular}{|c|c|c|c|c|c|c|c|}
\hline \multirow[t]{2}{*}{ Model } & \multicolumn{2}{|c|}{$\begin{array}{l}\text { Unstandardised } \\
\text { coefficients }\end{array}$} & \multirow{2}{*}{$\begin{array}{c}\begin{array}{l}\text { Standardised } \\
\text { coefficients }\end{array} \\
\text { Beta }\end{array}$} & \multirow[t]{2}{*}{$\mathrm{t}$} & \multirow[t]{2}{*}{ Sig. } & \multicolumn{2}{|c|}{$\begin{array}{l}\text { Collinearity } \\
\text { statistics }\end{array}$} \\
\hline & $\mathrm{B}$ & Std. error & & & & Tolerance & VIF \\
\hline $1 \quad$ (Constant) & .691 & .526 & & 1.312 & .191 & & \\
\hline Product quality & .162 & .069 & .130 & 2.345 & .020 & .886 & 1.129 \\
\hline
\end{tabular}




$\begin{array}{lcccrccc}\text { Product style } & .278 & .066 & .271 & 4.199 & .000 & .655 & 1.526 \\ \text { Product price } & -.173 & .061 & -.175 & -2.837 & .005 & .718 & 1.393 \\ \text { Brand image } & .442 & .091 & .386 & 4.875 & .000 & .434 & 2.302 \\ \text { Service quality } & -.078 & .078 & -.059 & -1.000 & .319 & .774 & 1.292 \\ \text { Store } & .240 & .086 & .199 & 2.791 & .006 & .539 & 1.857 \\ \text { environment } & .240 & & & \end{array}$

a. Dependent variable: brand loyalty

The regression equation based on Table 6 is

Brand loyalty $=0.691+0.162$ Product Quality +0.278 Product Style -0.173 Product Price + 0.442 Brand Image -0.078 Service Quality +0.240 Store Environment

The regression equation indicates that product price and service quality have a negative relationship with brand loyalty instead of a positive relationship as per earlier predictions; therefore, $\mathrm{H}_{3}$ and $\mathrm{H}_{5}$ are rejected. All independent variables except service quality have a significant value less than 0.05 , therefore $\mathrm{H}_{1}, \mathrm{H}_{2}, \mathrm{H}_{4}$, and $\mathrm{H}_{6}$ are supported. In addition, all variation inflation factor (VIF) scores are less than 5, indicating that there are not any multicolinearity issues in this study. Brand image is the most influential independent variable towards brand loyalty in the footwear industry among Malaysians, as it has the highest standardised coefficients value of 0.386 .

\section{HIERARCHICAL MULTIPLE REGRESSION ANALYSIS}

A hierarchical multiple regression analysis was performed using SPSS and PROCESS macros for SPSS to assess if generational cohort had an interaction with product quality, product style, product price, brand image, service quality, and store environment in moderating brand loyalty. In the first step, each construct and generational cohort were included. Next, the interaction term between the construct and generational cohort was added to the regression model. Figure 2 illustrates the procedure. The summarised result of the moderating analysis is tabulated in Table 7. These variables were mean centred before analysis.

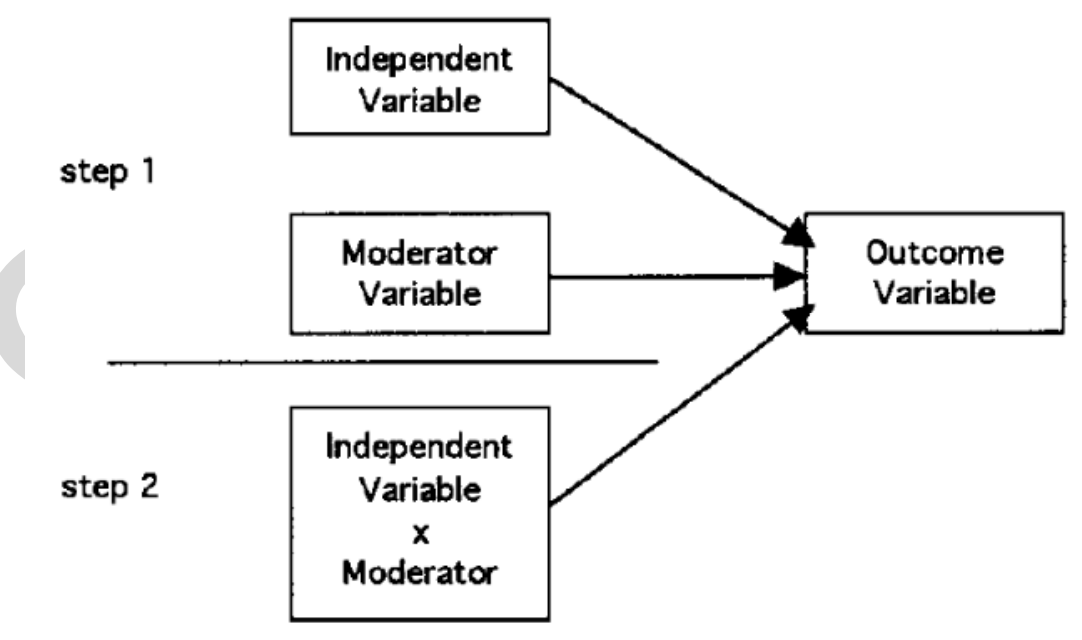

Source: Bennett, J.A. (2000), Figure 3, p. 471

FIGURE 2. Statistical model of a moderator effect

TABLE 7. Hierarchical multiple regression analysis (loyalty is a dependent variable)

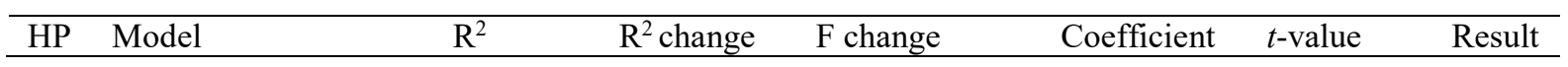




\begin{tabular}{lllllccc}
\hline $\mathrm{H}_{7 \mathrm{a}}$ & Product quality & $0.3031^{* *}$ & 0.0097 & $2.7291^{* *}$ & 0.2630 & $3.5252^{* *}$ & $\mathrm{NS}$ \\
& Generation cohort & & & & 0.4861 & $7.1577^{* *}$ & \\
& Interaction & & & 0.1726 & 1.652 & \\
$\mathrm{H}_{7 \mathrm{~b}}$ & Product style & $0.4784^{* *}$ & $0.0492^{* *}$ & $18.4696^{* *}$ & 0.3823 & $6.7081^{* *}$ & $\mathrm{~S}$ \\
& Generation cohort & & & & 0.4291 & $7.4287^{* *}$ & \\
& Interaction & & & & -0.3135 & $-4.2976^{* *}$ & \\
$\mathrm{H}_{7 \mathrm{c}}$ & Product price & $0.2819^{* *}$ & $0.0177^{*}$ & $4.840^{*}$ & 0.0819 & 1.32 & $\mathrm{~S}$ \\
& Generation cohort & & & & 0.5042 & $7.5144^{* *}$ & \\
& Interaction & & & -0.1737 & $-2.20^{*}$ & \\
$\mathrm{H}_{7 \mathrm{~d}}$ & Brand image & $0.6045^{* *}$ & $0.0478^{* *}$ & $23.6966^{* *}$ & 0.4457 & $6.9204^{* *}$ & $\mathrm{~S}$ \\
& Generation cohort & & & & 0.4796 & $9.8075^{* *}$ & \\
& Interaction & & & -0.3917 & $-4.8670^{* *}$ & \\
$\mathrm{H}_{7 \mathrm{e}}$ & Service quality & $0.2576^{* *}$ & 0.00 & 0.0047 & 0.1124 & 1.3090 & $\mathrm{NS}$ \\
& Generation cohort & & & & 0.5268 & $7.8425^{* *}$ & \\
& Interaction & & & & -0.0072 & -0.0688 & \\
$\mathrm{H}_{7 \mathrm{f}}$ & Store environment & $0.6093^{* *}$ & $0.0987^{* *}$ & $49.5145^{* *}$ & 0.4572 & $7.7991^{* *}$ & $\mathrm{~S}$ \\
& Generation cohort & & & & 0.5101 & $10.5481^{* *}$ & \\
& Interaction & & & & -0.5301 & $-7.0367^{* *}$ & \\
\hline
\end{tabular}

Note: $\mathrm{HP}=$ Hypothesis, ${ }^{* *} p<0.01,{ }^{*} p<0.05, \mathrm{~S}=$ supported, $\mathrm{NS}=$ not supported

Based on the R square change column tabulated results in Table 7 , generational cohort significantly moderates the effect of product style, product price, brand image, and store environment on the brand loyalty in the footwear industry among Malaysians, with the $\mathrm{R}$ square change ranging from $1.77 \%$ to $9.87 \%$, Hence, $\mathrm{H}_{7 b}, \mathrm{H}_{7 c}, \mathrm{H}_{7 \mathrm{~d}}$, and $\mathrm{H}_{7 \mathrm{f}}$ are supported. Meanwhile, generational cohort does not have much effect on product quality and service quality, as the $\mathrm{R}$ square changes are not significant; therefore, $\mathrm{H}_{7 \mathrm{a}}$ and $\mathrm{H}_{7 \mathrm{e}}$ are not supported.

TABLE 8. Conditional effects of the focal predictor at values of the moderator(s) based on the Johnson-Neyman technique

\begin{tabular}{cccc}
\hline \multirow{2}{*}{ Focal predictor } & \multicolumn{3}{c}{ Effects } \\
\cline { 2 - 4 } & The Millennials & Generation X & Baby Boomers \\
\hline Product style & $0.6520^{* *}$ & $0.3385^{* *}$ & 0.0249 \\
Product price & $0.2313^{*}$ & 0.0576 & -0.1160 \\
Brand image & $0.7825^{* *}$ & $0.3909^{* *}$ & -0.0008 \\
Store environment & $0.9131^{* *}$ & $0.3830^{* *}$ & -0.1472 \\
\hline
\end{tabular}

Note: $* * p<0.01, * p<0.05$

\section{DISCUSSIONS, IMPLICATIONS, AND LIMITATIONS}

Much research and several empirical studies of brand loyalty in the footwear industry have been performed in other countries: India (Anitha 2014), China (Li 2013), and Finland (Rubini 2010), but not in Malaysia. However, it is clear that demographic and geographic factors do play a role in influencing brand loyalty among its consumers. This is the main research contribution to knowledge related to studying the effects of brand loyalty on the footwear industry in Malaysia and identifying the moderating effects of generational cohort on brand loyalty in the footwear industry among Malaysians.

Based on the multiple regression analysis performed, brand loyalty in the footwear industry among Malaysians is positively influenced by four factors: product quality, product style, brand image, and store environment. In addition, product price showed a significant negative relationship with brand loyalty. The only independent variable that does not influence brand loyalty in the footwear industry is service quality.

According to the findings, generational cohort has effective moderating effects on product style, product price, brand image, and store environment towards brand loyalty in the footwear 
industry among Malaysians. Among these factors, generational cohort shows the strongest moderating effects between the store environment and brand loyalty with an $\mathrm{R}$ square change of $9.87 \%$. The study of conditional effects of the moderator, based on the Johnson-Neyman technique, revealed that Millennials show a significant positive relationship with product styles, product price, brand image, and store environment towards customer loyalty. Millennials exhibited the greatest positive effect (0.9131) between store environment and loyalty. In addition, Generation X demonstrated a significant positive effect on product style, brand image, and store environment towards loyalty. However, Baby Boomers do not have a significant effect on any of the independent variables with loyalty.

One managerial implication drawn from this study is that more research should be done on designing and producing comfortable footwear. First, this follows the finding that footwear made of comfortable material is the most important aspect of product quality. Second, respondents admitted to being loyal to brands that provide attractive shoe styles and a wide variety of footwear. Third, brands that provide good value for money were able to stimulate their consumers' loyalty. Therefore, footwear companies should accentuate the gathering of frequent consumer and user feedback to determine their products' faults to enhance their end products.

Managers should also direct their effort and resources towards maintaining or enhancing their brand image, as respondents said that a reputable brand image is important to inspiring brand loyalty. In addition, this study indicates that the most important aspect of store environment is a pleasurable shopping environment. Another noteworthy managerial implication of this study is that service quality was found to be insignificant in influencing brand loyalty in the footwear industry among Malaysians. The surge in online shopping among Malaysians may explain the unimportance of service quality among consumers. Nevertheless, managers should not neglect good customer service at brick-and-mortar stores, because they are still relevant to some customers.

Finally, the discovery that generational cohorts significantly moderate the factors that affect brand loyalty in the footwear industry among Malaysians has several managerial implications. Most importantly, this finding reveals that consumers from different age groups have different purchasing patterns and buying behaviour owing to their varying histories, lifestyles, values, and expectations. Thus, it is vital for managers to recognise this and initiate multi-generational marketing. Multi-generational marketing is a strategy to satisfy the wants and needs of consumers from various generational cohorts (Williams \& Page 2014).

Although this research makes several contributions to the footwear industry, numerous limitations were identified while this study was being conducted. The concentration of the survey distribution was geographically limited mostly to the citizens of Melaka, Johor, and Kuala Lumpur, owing to time and financial constraints. Because the snowball non-probability sampling method was used, it is clear from the descriptive analysis of respondents' demographic profiles that most of the respondents were of Chinese ethnicity. An empirical study conducted by Wong and Sidek (2008) demonstrates that promotion affected brand loyalty among Malaysians. Meanwhile another study by Muhammad et al. (2013) reveals that ease of use, advertising, and brand awareness were important factors influencing brand loyalty among consumers. Hence, a further recommendation would be to perform empirical studies on these other existing variables, which may be antecedents of brand loyalty in the footwear industry.

\section{REFERENCES}

Abdullah, A. 2015. Perceived quality, brand Image and brand trust as determinants of brand loyalty. Journal of Research in Business and Management 3(4): 1-8. 
Anitha, L. 2014. Brand loyalty and brand preferences of women in the choice of foot wear in Coimbatore City, Tamil Nadu. International Journal of Engineering and Management Research 4(2): 1-11.

Assuncao, J., Faria, S., Carvalho, V. \& Ferreira, P. 2013. The impact of store environment on shopping behaviour and loyalty. Studies of Organisational Manage and Sustainability 2(1): 26-35.

Aznam Shah, S. 2018. Time for local shoemakers to innovate. The Malaysian Reserve. Available at https://themalaysianreserve.com/2018/06/11/time-for-local-shoemakers-toinnovate/

Bennett, J.A. 2000. Mediator and moderator variables in nursing research, conceptual and statistical differences. Research in Nursing and Health 23: 415-420

Brandmovers. 2018. From B to Z: consumer loyalty behavior by generation. Available at http://brandmovers.com/2018/01/08/b-z-consumer-loyalty-behavior-generation/

Canning, N. 2017. How loyal is the baby boomer generation? Available at https://www.brandfire.ie/2017/03/30/how-loyal-is-the-baby-boomer-generation/

Che Wel, C.A., Shah Alam, S. \& Mohd Nor, S. 2011. Factors affecting brand loyalty: An empirical study in Malaysia. Australian Journal of Basic and Applied Sciences 5(12): 777 $-783$.

Choi, W., Heo, J. \& Kim, M. 2012. Effects of physical environment on brand loyalty and moderated effects of brand image. International Proceedings of Economics Development and Research 56(12): 57-61.

Chong, L., Low, K., Tai, G., Tan, L. \& Tan, S. 2015. Customer loyalty in airline industry Malaysia. Bsc Diss. Universiti Tunku Abdul Rahman, Kuala Lumpur, Malaysia. Available at http://eprints.utar.edu.my/1802/1/BAC-2015-1206820-1.pdf

Chumpitaz, R. \& Swaen, V. 2003. Service quality and brand loyalty relationships: Investigating the mediating effect of customer satisfaction. Institut d'Economie Scientifique Et de Gestion (IESEG) School of Management, 1-7.

Creusen, M. \& Schoormans, J. 2005. The different roles of product appearance in consumer choice. The Journal of Product Innovation Management 22: 63-81.

Dai, X.X. \& Chen, K.C. 2017 Examining antecedents of brand loyalty on sportswear: An empirical investigation of university students in Hong Kong. International Journal of Social Science Study 5(7): 87-96.

Dhurup, M., Mafini, C. \& Dumasi, T. 2014. The impact of packaging, price and brand awareness on brand loyalty; Evidence from the paint retailing industry. Acta Commercii $14(1): 1-9$.

Ferencic, M. \& Wolfling, A. 2013. Impact of quality inconsistency on brand loyalty. Congress Proceedings Marketing in a Dynamic Environment, 491-506. Croatia: Academic and Practical Insights.

Fundera. 2017. 13 Brand loyalty statistics you need to know to keep your customers coming back. Available at https://www.fundera.com/resources/brand-loyalty-statistics

Gilboa, S. \& Vilnai-Yavetz, I. 2010. Four generations of mall visitors in Israel: A study of mall activities, visiting patterns, and products purchased. Journal of Retailing and Consumer Services 17: 501-511.

Glover, J. 2018. Age matters - Generational marketing from baby boomers to GenZ. Available at http://customerthink.com/age-matters-generational-marketing-from-baby-boomers-togenzl

Hamza Salim, K. 2011. The influence of brand loyalty on cosmestics buying behaviour of UAE female consumers. International Journal of Marketing Studies 3(2) : 123-33.

Hayan, D. \& Samaan, A. 2015. The effects of the determinants of customer satisfaction on brand loyalty. Journal of Research in Business and Management 3(3) : 1-12. 
Hill, R. 1998. What sample size is "Enough" in internet survey research? Interpersonal Computing and Technology Journal 6(3): 1-10.

Horvath, D. 2001. The role of product design in product related consumer judgements. Unpublished Ph.D. Dissertation, Budapest University of Economic Sciences and Public Administration.

Industry Insights. 2017. Consumers Confirm Loyalty to Retailers, Product-Brands. ICSC Research. Available at https://www.icsc.org/uploads/t07-subpage/Consumer-ConfirmLoyalty-to-Retailers.pdf

Indrayani, E., Siringoringo, H. \& Saptariani, T. 2008. Impact of price on brand loyalty sensitivity. Delhi Business Review 9(2): 17-25

Italian Trade Agency. 2012. An overview on Malaysian footwear industry. Via Liszt, Rome, Italy.

Jackson, V., Stoel, L. \& Brantley, A. 2011. Mall attributes and shopping value: Differences by gender and generational cohort. Journal of Retailing and Consumer Services 18: 1-9.

Khoei, R. 2014. Brand loyalty in sportswear in Iran. International Journal of Management, Accounting and Economics 1(1): 52-80.

Kinuthia, L., Mbrurugu, K., Muthomi, H. \& Mwihaki, M. 2012. Factors influencing brand loyalty in sportswear among Kenyan University Students: The Case of Swimmers. Asian Journal of Social Sciences \& Humanities 1(4): 223-231.

Krishnakumar, K. \& Kavitha, S. 2014. Brand loyalty on footwear. Global Journal For Research Analysis International 3(4): 13-16.

Kumar, A. \& Kim, Y. 2014. The store-as-a-brand strategy: The effect of store environment on customer responses. Journal of Retailing and Consumer Services 21(1): 685-695.

Li, J. 2013. Factors affection customer satisfaction and customer loyalty towards Belle Footwear Company in Lanzhou City, Gansu Province of the People Republic of China. IOSR Journal of Business and Management 14(2): 41-48.

Lim, R. \& Aprianingsih. 2015. Factors influencing brand loyalty towards sportswear in Bandung. Journal of Business and Management 4(8): 932-943.

Lin, T. \& Chang, M. 2013. A study of the factors that influence the brand loyalty of Taiwanese adolescents with respect to purchasing mobile. The case of Taichung City. Problems and Perspective in Management 11(2): 86-97.

Lissitsa, S. \& Kol, O. 2016. Generation X vs. Generation Y - A decade of online shopping. Journal of Retailing and Consumer Services 31: 304-312.

Live Population. 2010. Population of Malaysia. Available at http://www.livepopulation.com/ country/malaysia.html

Maheshwari, V., Lodorfos, G. \& Jacobsen, S. 2014. Determinants of brand loyalty: A study of the experience-commitment-loyalty constructs. International Journal of Business Administration 5(6): 13-23.

Malaysia Insights. 2014. Malaysia's shoe industry steps up. Available at http://www.malaysiainsights.com/malaysias-shoe-industry-steps-up/

MATRADE. 2015. Malaysia stamping its mark in global footwear and fashion accessories market. Available at http://www.matrade.gov.my/en/about-matrade/media/pressreleases/press-releases-2015/4051-malaysia-stamping-its-mark-in-global-footwear-andfashion-accessories-market-30-june-2015

MATRADE. 2017. Footwear exports down $12 \%$ in 1 st 8 months of 2017 . Available at http://www.matrade.gov.my/en/jp/about-matrade/media/news-clippings/156-newsclippings/news-clippings-2017/4067-footwear-exports-down-12percent-in-1st-8-monthsof-2017 
McCrindle, M. 2011. Generations defined. In The ABC of XYZ: Understanding the Global Generations, edited by M. McCrindle, \& E. Wolfinger, 1-22. New South Wales: UNSW Press.

Muhammad, D., Seyyed Mohammad, N. \& Nima, B. 2013. Factors and elements influencing brand loyalty: A case study in customers of Khazar gaz in Mazandaran. International Journal of Agriculture and Crop Siences 6(11) : 712-715.

Neuman, W. 2012. Basics of Social Research: Qualitative and Quantitative Approaches. Boston: Pearson Education.

North, E., De Vos, R. \& Kotze, T. 2003. Importance of apparel product attributes for female buyers. Journal of Family Ecology and Consumer Sciences 31(1): 41-51.

Parment, A. 2013. Generation Y vs. baby boomers: Shopping behaviour, buying involvement and implications for retailing. Journal of Retailing and Consumer Service 20 : 189-199.

Pentecost, R. \& Andrews, L. 2010. Fashion retailing and the bottom line: The effects of generational cohorts, gender, fashion fanship, attitudes and impulse buying on fashion expenditure. Journal of Retailing and Consumer Services 17(1) : 43-52.

Poku, K., Zakari, M. \& Soali, A. 2013. Impact of service quality on customer loyalty in the hotel industry: An empirical study from Ghana. International Review of Management and Business Research 2(2): 600-609.

Rubini, A. 2010. The role of brand in consumer behaviour: How sneakers have turned into a status symbol. Bsc Diss. Savonia University of Applied Sciences. Available at http://citeseerx.ist.psu.edu/viewdoc/download?doi=10.1.1.956.8782\&rep=rep1\&type=pd $\mathrm{f}$

Sekaran, U. \& Bougie, R. 2010. Research Methods for Business: A Skill Building Approach. 5th edition. USA: Wiley.

Singh, R. 2016. Factors affecting brand loyalty in the footwear industry - A study on Ludhiana District. International Journal of Research-Granthaalayah 4(6): 139-149.

Stevenson, W. \& Chuong, S. 2014. Operations Management. 2nd edition. Asia Global Edition: McGraw Hill.

Thompson, F., Newman, A. \& Liu, M. n.d. The impact of culture on brand loyalty - A study of the young affluent chinese. 1-11. Available at https://www.yumpu.com/en/document/ view/26157477/1-the-impact-of-culture-on-brand-loyalty-a-study-of-the-young-

Tsang, K. 2012. The use of midpoint on Likert Scale: The implications for educational research. Hong Kong Teachers' Centre Journal 11: 121-130.

Wagner, N. 2018. The brand loyalty of generation X. Available at https://stevenstate.com/blog/articles/the-brand-loyalty-of-generation-X/

Williams, K. \& Page, R. 2014. Marketing to the generations. Journal of Behavioural Studies in Business: $1-17$.

Wong, F. \& Sidek, Y. 2008. Influence of brand loyalty on consumer sportwear. International Journal of Economics and Management 2(2): 221-236.

Zehir, C., Sahin, A., Kitapci, H. \& Ozsahin, M. 2011. The effects of brand communication and service quality in building brand loyalty through brand trust: the empirical research on global brands. International Strategic Management 24(1): 1218-1231. 
Lai Ruixia

Faculty of Business

Multimedia University

Jalan Ayer Keroh Lama

75450 Bukit Beruang, Melaka, MALAYSIA.

E-Mail: lairuixia@gmail.com

Teo Siew Chein (corresponding author)

Faculty of Business

Multimedia University

Jalan Ayer Keroh Lama

75450 Bukit Beruang, Melaka, MALAYSIA.

E-Mail: scteo@mmu.edu.my 